\section{Crisis in Venezuela, or the Bolivarian Dilemma: To Revolutionize or to Perish? A Kaleckian Interpretation}

Review of Radical Political Economics $|-2|$

(C) 2016 Union for Radical Political Economics Reprints and permissions: sagepub.com/journalsPermissions.nav DOI: 10.1I77/04866I34I5623259 rrpe.sagepub.com

(\$SAGE

\author{
Roberto Lampa'
}

\begin{abstract}
This paper investigates the evolution of Venezuela's political and economic scenario over the last 15 years. I explore in depth both the achievements and the unsolved problems of the Venezuelan demand-led growth model. Recalling Kalecki's analysis of underdevelopment, I highlight Venezuela's problems that depend on the constraining role played by the existing institutions. I conclude that the real challenge consists of a deep institutional change, possibly along the lines portrayed in the 2007 constitutional referendum.
\end{abstract}

JEL classification: $\mathrm{O} I \mathrm{I}, \mathrm{HI}$, P2I

\title{
Keywords
}

Chavism, crisis, Kalecki, development economics, socialist theory

\section{Introduction}

Chavism has generally been interpreted as an autocratic regime by its critics, who often emphasize the lack of any coherent growth paradigm, the opportunistic use of public expenditures, and the inefficiency of its functionaries (Rodriguez 2003). In short, Chavism is seen as little more than a detrimental replay of a familiar Latin-American phenomenon, namely populism. However, such analyses deliberately ignore Chavism's most salient peculiarity in comparison to traditional populist governments: in 2007, Venezuelan President Hugo Chávez formulated a series of proposals aimed at transforming the country into a socialist country of the 21 st century, which inescapably determined both an increasing polarization of socio-economic classes and bitter social conflict. Populism, on the other hand, has been traditionally characterized by cross-class alliances (O’Donnell 1978).

\footnotetext{
'CONICET (National Scientific and Technical Research Council) and IDAES-Universidad Nacional de San Martin, Ciudad Autonoma de, Buenos Aires, Argentina
}

Date received: August 23, 2013

Date accepted: November I, 2014

\section{Corresponding Author:}

Roberto Lampa , CONICET (National Scientific and Technical Research Council) and IDAES-Universidad Nacional de San Martin, J. A. Cabrera 4587 (D. to B.), Ciudad Autonoma de, Buenos Aires, I3I3 Argentina.

Email: robertolampa@gmail.com 
Recently in this journal, Orhangazi (2014) shed light on the real features of the Bolivarian Revolution, implicitly re-igniting the debate around Venezuela's prospects. ${ }^{1}$ Nevertheless, his analysis fails to provide a theoretical interpretation of the facts it deals with. Furthermore, it tends somehow to minimize the severe contingencies (both political and economic) that the country is currently going through.

Unlike Orhangazi, I am persuaded that an economic analysis of Bolivarian Venezuela reveals a rather worrying scenario. On the one hand, from 2003 to 2007 the Venezuelan government successfully implemented an unprecedented growth paradigm by means of a demand-oriented strategy, which eventually determined an unparalleled economic expansion and a dramatic reduction of both poverty (which declined by 15.4 percent) and extreme poverty (which dropped by 9.2 percent). Such a growth paradigm was an effective short-term solution to the structural problems of the Venezuelan economy, as addressed in the pioneering works of Celso Furtado (1957; Medeiros 2006).

On the other hand, the government also faced two serious downturns (2002-2003 and 20082013) that revealed a troubling lack of control over several strategic branches of the economy, particularly the electrical and financial sectors and the importation (and distribution) of consumer goods. Accordingly, increasing inflation, abrupt devaluation, and massive capital flight frustrated the expansionary effect of both fiscal and monetary policies, thus revealing the aforementioned growth paradigm to be less than sustainable, despite its short-term effectiveness.

Finally, since 2014, the macroeconomic outlook seems to be rapidly deteriorating. Notwithstanding a lack of reliable data, ${ }^{2}$ in 2014 the country experienced an estimated contraction in real GDP of -4 percent (IMF), an annual inflation rate of 63.4 percent (CEPAL 2014), and an estimated gap between the official and illegal exchange rate of the Venezuelan bolívar to U.S. dollars of almost 1,500 percent. Such a tendency seems to be confirmed by the IMF forecasts for 2015 , which project a real GDP contraction of -7 percent together with an annual inflation rate of 96.8 percent and a sharp rise in unemployment (12.8 percent). The exchange rate gap currently reached the astonishing level of 11,163 percent ( 1 US $\$=703$ bolívares in the illegal market).

The seminal works of Michał Kalecki $(1949,1951,1955,1964,1966)$ on peripheral capitalist economies can provide a theoretical framework for understanding (or analysis) of the interrelation between the contradictory outcomes of Venezuela's Bolivarian Revolution and for interpretation of the origins of the severe political crises (the so-called guarimbas ${ }^{3}$ ) that have been shaking the country for months. Stated succinctly, Kalecki's approach emphasizes the several institutional and structural constraints that prevent the effectiveness of fiscal and monetary stimulus in an underdeveloped non-socialist economy. From this perspective, both inflation and capital flight are but sub-products of the political struggle between the government and working class and the rentier and capitalist elites. Thus a solution would lie in the transformation of the monetary and fiscal institutions, allowing government to cope with these economic problems in a more effective way. In the absence of resolute reforms, the crisis may well become a quasi-permanent state of affairs, thus threatening the existence of the government itself.

In light of this premise, this article first aims at reconstructing the origins of Chavism, both as a part of and an exception to the Latin American political and economic milieu. In particular, it is necessary to highlight certain aspects ignored by Orhangazi in order to better recognize the

\footnotetext{
${ }^{1}$ A remarkable descriptive analysis can also be found in Vera (2014).

${ }^{2}$ During 2014, the Central Bank of Venezuela did not publish several economic data such as GDP, imports, or the Consumer Price Index (CEPAL), thus affecting also the international databases (IMF, CEPAL, World Bank). At the present time (August 2015), a 2015 CPI series is still unavailable. Accordingly, my analysis covers the period 2003 to 2013 in order to avoid any possible methodological confusion.

${ }^{3} \mathrm{~A}$ guarimba is a violent protest, normally consisting of blocking of roads, lighting of tires, etc. It often involves acts of rock-throwing or even shooting against both police and political adversaries.
} 
country's future challenges, particularly with respect to the economy. Second, I aim to provide an interpretation of the present political crisis in Venezuela based on Kalecki's aforementioned articles on underdevelopment and the political aspects of state interventionism. ${ }^{4}$ Finally, I try to outline a possible strategy to counteract the difficult contingencies of Bolivarian Venezuela based on both Kalecki and Oskar Lange's work $(1937,1945)$ on socialist "mixed economies."

In section I I explore common features shared by Chavism and other regional neo-populist governments. In section II I pursue the idea that Chavism attempted to go beyond populism to represent a 21 st century socialist exception within the South American context. In section III I perform an economic analysis of Venezuela's most important achievements between 2003 and 2007. In section IV I highlight the unresolved issues of the economy and propose an interpretation based on Kalecki's analysis ${ }^{5}$ of the political implications of such an economic outlook. Finally, in section V, I draw certain conclusions about the relationship between (capitalist) institutional constraints and Chavist Venezuela's economic development, also suggesting some possible policy implications along the lines described by Oskar Lange.

\section{Chavism as Part of a Regional Trend}

One may legitimately interpret the Bolivarian Revolution in light of the broader political and economic changes experienced in South America since the end of the 1990s. However, in order to understand that process, one must also examine the prior situation, which is to say the fiasco of neoliberal adjustments supported by the Washington Consensus, which culminated in the continental sovereign debt crises of the 1990s.

In Venezuela's case, economic collapse actually predates a similar decline in the rest of the region, occurring in the 1989-1993 period during the presidency of Carlos Andrés Pérez. Until 1988, Venezuela had largely maintained a consistent economic structure, based on oil revenue and state enterprises; the country had also implemented policies aimed at substituting (traditionally high) imports. However, the sharp deterioration of oil prices in the late 1980s affected the macroeconomic indicators: the rate of inflation reached 29.5 percent in 1988, the current account deficit grew to US $\$ 5.8$ billion, and international reserves fell sharply, by US $\$ 9.5$ billion, between 1986 and 1988. In light of this scenario, the Pérez government repeatedly emphasized the necessity of rethinking the entire Venezuelan economy. He therefore presented a neoliberal economic package, ambitiously known as "El Gran Viraje" (the great turnabout) and consisting of three main elements. First, adjustment would be the key mechanism for re-establishing short-term equilibrium in the main macroeconomic indicators and for repaying the external debt. Second, Venezuela had to shift from a state-directed and oil-dependent economy to a market economy based on private and tradable exports. Third, the political system would have to change as well, from "populist" to "modern," that is to a minimal system that would not interfere with the free operation of the market.

Despite Pérez's emphasis on changes to policy, the new economic agenda proved to be essentially the same as that suggested by a prior mission of the International Monetary Fund (IMF), which in 1987 tied its loan to Venezuela to a long series of prescriptions (Lander 1996). In particular, the country had to restrict its public expenditures; squeeze wage levels; deregulate and devaluate the exchange rate; remove price controls; reduce subsidies; and liberalize imports.

\footnotetext{
${ }^{4}$ More precisely, using the criterion of philological precision side-by-side with that of empirical relevance (Roncaglia 2005), I seek to locate the connecting line of development between Kalecki's analysis and current debates on Venezuela. Therefore, by "Kaleckian interpretation" I do not mean a specific method of model-building (dealing with growth, distribution, instability, cycles, etc.) but rather a theoretical explanation of stylized economic facts, based on rigorous use of Kalecki's selected sources.

${ }^{5}$ See the disclaimer in note 2 , above.
} 
As may now seem predictable, the consequences of "Pérez-nomics" on the (already fragile) economy of Venezuela were absolutely negative, from any reasonable point of view: ineffective as well as inequitable. From 1988 to 1989 , the rate of unemployment increased from 6.9 percent to 9.6 percent (from 455,444 to 661,884 persons unemployed). Meanwhile, real wages fell to their minimum level: in 1990, the average was 50.2 percent below the maximum historical level, dated 1950. The share of real labor income over national income fell to 22.4 percent in 1990, from 50.2 percent in 1983 (Lander 1996). Of course, distribution of income was also deeply affected by these adjustments. Even the slight economic recovery shown in 1991-1992 was simply the ephemeral effect of public expenditures financed by foreign loans; as a matter of fact, that economic growth had already ended by 1992, and reserves were lower than prior to 1989 . Furthermore, increased financial fragility provoked a subsequent financial crisis which erupted with the 1994 bankruptcy of the Banco Latino: the government's decision to rescue the bank led inescapably to a strong fiscal deficit and, eventually, to a crisis of the whole financial system.

Both the birth and the rise of Chavism were clearly tied to social reactions to the Pérez adjustments. First, on February 27, 1989, a massive and tumultuous rebellion (El Caracazo) inflamed the streets of Caracas. Although the repression was brutal, ${ }^{6}$ Hugo Chávez Frias was one of the few disobedient officers who firmly refused to take part in it. The army punished him by means of strict disciplinary measures which consecrated Chávez as an "amigo del pueblo" (a friend of the people) in public opinion (Lander 1996). Subsequently, and most importantly, on February 4, 1992, Chávez led a failed coup d'etat against Pérez. Before surrendering, he spoke to the nation via national broadcast, assuming complete responsibility and thus becoming the leader of the self-declared Bolivarian insurrection against the adjustments and neoliberalism in general (Cisneros 2009). His popularity grew rapidly: in November 1992, a second (failed) coup tried to liberate him from prison; in 1998, he decisively won the presidential election against the conservative entrepreneur Enrique Salas Romer (receiving 56 percent of votes, versus Romer's 35 percent); finally, in 2002-2003 he managed to resist both a counter-coup and a massive oil strike and economic boycott led by the Chambers of Commerce (FEDERCAMARAS).

From this perspective, the Chávez government certainly shared several features with so-called neo-populism ${ }^{7}$ (Calcaño et al. 2002). First, his discourse was definitely anti-political and similar to the Argentinian cry "ique se vayan todos!" (throw them all out!), as pre-existing institutions and political parties were unequivocally accused of being responsible for the economic crisis. Not coincidentally, Chávez's electoral platform in 1998 was originally called Movimiento $V$ República (Movement for the Fifth Republic) in order to stress the need for a blank slate. Indeed, after his electoral victory, Chávez proposed a new constitution. This was drafted in 1999 by a specifically elected constitutional assembly and presented to the national electorate in December 1999, being approved with 71.8 percent of votes. Accordingly, the country's name and flag were changed from "Venezuela" to the "Bolivarian Republic of Venezuela." Second, Chavism was based on both the charismatic leadership of its founding father (top-down dimension) and the permanent mobilization of its militants (bottom-up dimension), as in traditional populism. Third, nationalism represented a crucial element of Chavism: on several occasions, Chávez described himself as the loyal heir of Simón Bolívar, reclaiming the 19th century Liberator's idea of a Patria Grande (Great Fatherland) among the South American peoples. Fourth, and like Perón in Argentina, Chávez was a colonel who gave much importance to the role of the army in the political process (Arena 2004). Consequently, he also used many topoi of traditional populism; for

\footnotetext{
${ }^{6}$ Independent sources stress that El Caracazo resulted in more than 3,500 dead.

${ }^{7}$ According to Calcaño y Arenas, neo-populism differs from traditional populism, since the latter represented an attempt to forcibly modernize the South American region, whereas the former arose from the collapse of existing institutions; that is, from the exhaustion of the prior neoliberal "modernizing" process.
} 
instance, he repeatedly emphasized the existence of enemies that threatened the Bolivarian Revolution. Internally, these were represented by the "rotten and corrupted oligarchy" that conspired against the national interests in order to increase their own wealth. Abroad, the enemy was embodied by the United States and in particular by then-president George W. Bush, to whom Chávez addressed several memorable invectives.

Thus one may conclude that Chavism was part of a regional trend that grew in the early 2000s, characterized by both strong opposition to neoliberalism and the construction of international alliances aimed at counteracting the traditional influence of the United States and the IMF on Latin American economies; momentum for this trend was further driven by the failure of Bush's proposed AFTA (American Free Trade Association) at the IV Cumbre de las Américas summit held in 2005 in Mar del Plata, Argentina.

\section{Chavism as an Exception to the Regional Trend: The $\mathbf{2 0 0 7}$ Referendum}

"La igualdad factica, la igualdad política, la igualdad social, la igualdad económica [...] igualdad de resultados es más importante que igualdad de oportunidades." (Hugo Chávez Frias 2004, in Reyes 2006)

Notwithstanding the many similarities outlined in the previous section, I do not share the wide-spread view (common among both conservative and liberal scholars) that Chavism was quite like any other regional neo-populist movement (e.g. Ramos Jiménez 2002). Venezuela's peculiarity was that, especially after the 2006 elections, the Chávez government also formulated a long series of proposals aimed at transforming the country into a "socialist country of the $21 \mathrm{st}$ century."

As emphasized by Orhangazi (2014), from 1998 onward, Venezuela had nationalized many strategic parts of its national economy, first and foremost the oil company PDVSA (1999). As a result, by 2010, the public sector produced almost 30 percent of Venezuela's GDP (BCV 2011), thus showing clear expansion when compared to the pre-Chávez period characterized by massive privatization. The government also decided to act decisively in the agricultural branch: in 2003 it created the "Zamora mission," an institution allowing the redistribution of 3.6 million hectares (over 30 million acres) of expropriated agricultural land to 130,000 families.

Furthermore, as highlighted by Nakatani and Herrera (2008), following the 2001 Organic Law of Planning, the government created a series of local institutions aimed at organizing people's participation in public budgeting decisions: the Local Councils of Public Planning (which operate at city level); the District Councils (which in addition can manage local banks, financed by the government); and manufacturing cooperatives.

However, to my mind the most topical (as well as underrated) moment remains the proposal in 2007 of a radical review of the 1999 Constitution, amending 69 of 350 articles and explicitly aimed at transforming Venezuela into a "socialist country of the 21 st century." Even though the voters rejected such modifications by a narrow majority (50.65 percent $v s 49.35$ percent), the proposed changes revealed the peculiarity of Chavism compared to the rest of the region (Reyes 2006). First, the form of the state would have changed to a "mixed democracy," where traditional representative institutions coexist with several new institutions of direct participation. In particular, the legislative power would have been co-shared by both types of institutions, and voters would have been empowered to remove any existing public officer.

${ }^{8}$ Translation: "Factual equality, political equality, social equality, economic equality (...) equality of the results is more important than equality of opportunities." 
Second, the property regime would also become a mixed regime: although private property was not to be abolished, it would play a secondary role, becoming just one of the five possible types of property, together with public property (property of the state), social property (property of the councils), collective property (both in terms of natural resources and land, or the "commons"), and mixed property (property of the cooperatives). Furthermore, any expropriation would become self-executing since it would no longer be necessary to wait for a court's verdict. Third, the economy would also shift to a mixed economy: privately owned firms would be tolerated, but production could not aim exclusively at the maximization of profits. Economic activity would be carried out in order to cover all social needs, under two types of constraints: workers' participation in the management of the firm, and the firm's social responsibility for the environmental consequences of production. Moreover, the Central Bank would cease to be autonomous in order to harmonize fiscal and monetary policy. Fourth, access to welfare state provisions would no longer depend on the level and quality of one's job, but would rather become a universal human right, consisting of the equal redistribution of a certain fraction of the social surplus to the people.

In my view, such a reform would have transformed Venezuela into a particular (and untried) form of socialist economy, namely a socialist mixed economy. According to Oskar Lange (1945), in a socialist mixed economy production is operated by both private and state enterprises, but the government decides whether to leave production to the private sector or to manage it through public services, depending on which option promises to contribute more to the satisfaction of the social needs of the community. Lange further defines this as a service economy because production is assigned to that unit which best serves the collective interest. ${ }^{9}$ In other words, production is delegated to private firms by the government only if those firms can fill a need better than, or at least as well as, public agencies; therefore, private profits essentially depend on the achievement of social results. That is why, according to Lange, it is possible to define such an economy as a particular (though untried) type of socialist economy. ${ }^{10}$

Lange's definition might have perfectly described Venezuela's economy, had the 2007 constitutional referendum been victorious. However, its proposal and near-passage have the merit of clarifying several crucial differences between Chavism and traditional populism.

First, this attempt at transforming Venezuela into a socialist country reveals that the Chávez strategy did not include the conventional alliance among classes, guaranteed by state interventionism and typical of previous populist governments (O'Donnell 1978) as well as contemporary governments of the region, notably Argentina and Brazil (McGuire 2012). More precisely, the constitutional draft of 2007 departs from the traditional developmentalism of those governments. As a matter of fact, Chávez was not proposing a pact among producers aimed at freezing class conflict by degrees of both protectionism and redistribution, nor did he defend the traditional class division of the society in order to achieve economic development. On the contrary, the 2007 constitutional draft questioned the very idea of private property. The defeat of the referendum had crucial consequences for Venezuelan society. On the one hand, the bulk of Chávez's support increasingly came from the poorer and dark-skinned sectors. On the other, the wealthiest segment of society continuously radicalized its opposition to Chavism, even at the cost of profits, as

\footnotetext{
${ }^{9} \mathrm{Of}$ course, I am not referring to the current meaning of service economy, "an economy providing services as opposed to goods."

${ }^{10}$ Lange's definition might potentially cause some confusion, as mixed economy in the current economic debate usually refers to non-socialist economies with a certain degree of state interventionism. Nevertheless, one should not ignore that the term was formulated in the context of a broader proposal of reform of the U.S. economy, originally addressed to the Roosevelt administration in 1944. Euphemism was, therefore, inescapable. See Lange and Lerner (1944).
} 
demonstrated by the 2002-2003 oil strike and by the guarimbas that cyclically rocked the political and economic scene.

Therefore, the referendum's final result was an unprecedented polarization around class and racial subtexts within Venezuelan society, which eventually led to a strictly class-based political system (Cannon 2008) that dramatically differs from the rest of the region.

Second, once I contextualize Chávez's 2007 proposals in this way, a certain parallelism (virtually ignored by the majority of scholars and denied by Orhangazi 2014) with forthcoming reforms in Cuba seems inescapable (Lander 2008). In my opinion, such a parallelism is legitimate, bearing in mind also that the Cuban Revolution was not originally a socialist revolution, and that in the past decade the Cuban government has seriously debated ways to re-shape its institutions with regard to the relationship between state and market in order to avoid bureaucratism. Notoriously, among the most important reforms in Cuba are ones intended to expand the use of markets in building socialism, or, to put it differently, into a socialist mixed economy - and not to abandon socialism altogether, as has been recognized by anti-Cuban scholars (Mesa-Lago 2014) - and this is objectively quite close to the model advanced by Chávez in 2007.

From this perspective, the clear-cut statement by Harnecker (2005) about the unfillable distance between Chavism and Marxism needs revision, since it may hold true only for the early portion of the Bolivarian Revolution, and not for the frustrated political changes of 2007. Broadly speaking, one cannot ignore that in Latin America since the Cuban Revolution, Marxism has often been blended with national traditions of thought (such as Bolivarism), thus matching national sovereignty with economic liberation. Second and foremost, it is important to emphasize that not only Simón Bolívar but also Antonio Gramsci have represented seminal references in the definition of Chavist ideology. ${ }^{11}$ In particular, the deep transformation of local authorities into organs of communal power ("Poder Comunal"), as described by both Nakatani and Herrera (2008) and Ciccariello-Maher (2007), was actually aimed at the construction of a new historical hegemonic block, to direct the nation toward a "21st-century socialism."

In Gramscian terms, we can thus conclude that Chavism has not embodied the typical features of a populist passive revolution" ${ }^{12}$ : rather than circumscribing its area of action to a "conservative modernization" (a process of accelerated development that does not change, or even question, the conventional class structure of a society), the 2007 proposals showed Chavism to represent an ambitious, class-conscious, and socialist institutional alternative. One may therefore say that only in Venezuela did the initial anti-neoliberalism reaction abruptly evolve into anti-capitalism.

However, one must also note that since the failed constitutional referendum, such a project has been completely (and inexplicably) set aside. Stated succinctly, transformation of the Venezuelan institutions simply disappeared from the political agenda. In the following section, we shall examine the topical consequences of that controversial choice, particularly on the country's economy.

\section{The Glass Half Full: Chavism's Most Important Economic Achievements (2003-2007)}

The ambivalence of the Bolivarian Revolution has inescapably determined ambivalent results. We can divide the macroeconomic analysis into two periods: a first period (2003-2007) in which

\footnotetext{
${ }^{11}$ See, for instance, Chávez's memorable speech about Gramsci and the necessity of building up a new hegemonic historical block in order to transform Venezuela into a socialist country during the 2007 referendum campaign (Hugo Chavez presents Gramsci to hundreds of thousands of people. A beautiful revolution. 09/07/2007).

${ }^{12} \mathrm{An}$ alternative interpretation is in Laclau (2005), according to whom contemporary populism follows a logic of antagonism against the dominant block.
} 
the Chávez government very effectively managed the economy, and another period (or better yet two sub-periods, 2002-2003 and 2008-2013) in which Venezuela had to face severe circumstances. Here we will look at the successful period of Chávez's administration. ${ }^{13}$

As evidenced by the pioneering works of Celso Furtado (1957), Venezuela's economy had always suffered from a particular and heavy variation of the "Dutch disease" (Medeiros 2006). The abundance of oil had determined, on the one hand, a big influx of foreign currency and, on the other, an appreciated exchange rate. In addition, Venezuela had traditionally implemented a protectionist trade policy, in order to defend both its (backward) industry and its (low productive) agriculture. The combination of these factors determined a paradoxical result: when compared to international prices, both the domestic prices of Venezuelan consumer goods and monetary wages (expressed in US\$) were relatively high and, therefore, national commodities could not be traded abroad. Domestic protectionism forced workers to buy overpriced national goods, so that real wages were quite low. Consequently, Venezuela was not an export-led economy, nor did it take advantage of domestic demand: it remained an underdeveloped country, despite the remarkable surplus guaranteed by the oil branch. Furthermore, in the absence of any productive use, the enormous mass of capital was traditionally directed to U.S. financial markets, thus strengthening the hegemonic role played by the rentiers (essentially, those who controlled the oil trade), the bankers, and the financial brokers in Venezuelan society. In addition, the appreciated exchange rate strongly incentivized speculation in the currency market: when the (hard) currency approached its "perceived upper limit," devaluatory expectations determined massive capital flight. This scenario rapidly evolved into a typical self-fulfilling prophecy, as the government actually had to devaluate the national currency in order to stop the deleterious capital flight. Subsequently, capital was repatriated at much more favorable conditions, which eventually guaranteed a speculative markup. One might conclude that Venezuela has been both an underdeveloped and a capital-exporting country for decades; a bizarre picture, indeed.

Unlike Orhangazi (2014), I do not see the macroeconomics of Chavism as consisting of a repetition of such traditional (not to mention ineffective) economic policies. In my view, in 20032007, the Chávez administration managed to successfully correct a portion of the problems anticipated by Furtado by adopting a new growth paradigm.

Even though the government was not able to affect a change in the country's productive structure (which remained largely dependent on oil), or to implement significant industrial policies or economic planning programs (Nakatani et al. 2008), Venezuela was able to take advantage of a huge economic expansion by means of a demand-oriented strategy which led to unprecedented expansion of the domestic market.

Thanks to high prices on the barrel, the nationalized oil company PDVSA guaranteed an enormous infusion of financial resources into the government. ${ }^{14}$ However, unlike in the past, that surplus was entirely devoted to the expansion of domestic demand (rather than financial markets), that is to expansion of the purchasing power of wage earners, essentially by means of two mechanisms.

\footnotetext{
${ }^{13}$ Venezuela's political polarization has determined that the majority of publications do not share the same methodology (see Rodriguez 2003; Weisbrot 2008a, 2008b), nor do they agree on national accounting statistics, particularly the Consumer Price Index (which moreover was not published by the Central Bank of Venezuela (or BCV) for several months in 2014 and 2015. Furthermore BCV's nominal GDP has been expressed in bolivares until 2014, and the segmented exchange rate, introduced in 2010, implies a certain degree of difficulty for conversion to US\$. Accordingly, I have preferred to use data coming from international institutions: mainly CEPAL (ECLAC) but also the IMF and the World Bank. I make reference to the $\mathrm{BCV}$ statistics only in "non-controversial" cases, such as the exchange rate or the reserves.

${ }^{14}$ However, the government also significantly increased its collection of non-oil taxes (from 10 percent of GDP in 1999 to 12 percent in 2006) and income taxes (from 2 percent of GDP in 1999 to 3.2 percent in 2006) in order to finance the fiscal stimulus with domestic currency (Weisbrot et al. 2007).
} 
First, the Chávez government greatly increased social spending on (free and universal) health care, education, and subsidized foods. In 1998, there were 1,628 primary care centers in Venezuela (each with one physician), 417 emergency rooms, and 74 rehab centers. By 2007, those numbers had grown to 8,621 primary care centers (with 19,751 physicians), 721 emergency rooms, and 445 rehab centers. The number of students in primary schools increased during the 1999-2006 period from 271,593 to 1,098,489; furthermore, total students admitted to school food programs increased from 252,000 to $1,800,000 .{ }^{15}$ Finally, by 2006 there were 15,726 stores offering basic food items at subsidized prices (meaning 27 percent to 39 percent below average market prices). Together with the special programs for the extremely poor, this service benefited an average 67 percent of the population in 2005. Consequently, the poverty rate also decreased rapidly, from 55.1 percent in 2003 to 30.4 percent at the end of $2006 .{ }^{16}$ When compared to the pre-Chávez period, poverty was reduced by 31 percent (Weisbrot et al. 2007).

Second, the government kept the national currency appreciated with the goal of paying less for imports of consumer goods, rather than insisting on traditional protectionism. In other words, the government chose to subsidize domestic consumption through the inflow of foreign currency generated by the oil rent, which is an indirect way of redistributing income. This option was a necessary prerequisite for demand-led economic growth, ${ }^{17}$ as it allowed both a substantial increase in the stock of imported consumer goods available to national markets (particularly food and agricultural goods) as well as a dramatic lowering of their prices for Venezuelan consumers. As a matter of fact, the Chávez administration attained these goals rapidly: in 2003, imports were at US\$ 8.3 billion; in 2006 they reached US\$ 30.5 billion (IMF). Accordingly, the average inflation rate (consumer prices) decreased from 31.1 percent (in 2003) to 13.7 percent (in 2006) (CEPAL 2012). Of course, to increase these imports so strongly required careful attendance to both the external and internal balances; it also required a consistent stock of international reserves, in order to face any unexpected decline in oil revenues. In the 2003-2006 period, Venezuela achieved both these objectives: on the one hand, the country ran a commercial surplus (US\$ 35 billion in 2006) and total public debt decreased from 47.7 percent of GDP (2003) to 23.8 percent (2006); on the other hand, international reserves increased from US\$21.3 billion (2003) to US\$ 37.4 billion (2006) (CEPAL 2012; Weisbrot et al. 2007). Furthermore, to avoid capital flight and speculation in the currency market that the country had traditionally suffered when its currency was appreciated, the government in 2003 introduced a regime of capital control: any currency transaction to finance imports had to be submitted to a Currency Administration Commission (CADIVI), which processed applications to obtain foreign currencies. All in all, throughout the 2003-2007 period, such controls proved to be quite effective.

The combined effect of favorable oil prices and a robust fiscal stimulus generated abrupt and impressive economic growth: in 2004, real GDP increased by 18.3 percent; in 2005 by 10.3 percent; in 2006 by 9.9 percent; and in 2007 by 8.8 percent. Accordingly, the unemployment rate fell, from 18.4 percent in June 2003 to 8.3 percent in June 2007 (CEPAL 2012; Weisbrot and Sandoval 2007). Finally, it should be noted that the distribution of income also showed an impressive improvement, with the Gini index decreasing from 0.48 (2003) to 0.42 (2007) (CEPAL 2012).

\footnotetext{
${ }^{15}$ It must be mentioned that in underdeveloped countries, free education expands household purchasing power especially, because children are able to receive free meals in school dining halls.

${ }^{16}$ However, this measures only cash income and does not take into account advances in health care or education.

${ }^{17}$ Mendoza (2007) showed that, given the structure of consumption in Venezuela, currency devaluation immediately determines both a loss of purchasing power and an increase in the Gini index. Similar results have been evidenced by several works dealing with other regional economies, such as Lopez et al. (2011) in Mexico and Castresana et al. (2009) in Argentina.
} 


\section{Loose Ends to Tie Up: A Kaleckian Interpretation}

\section{I. Sailing in troubled waters: The macroeconomics of two crises (2002-2003 and 2008-20/3)}

Notwithstanding its unquestionable achievements, Chavism had to face two serious downturns (2002-2003 and 2008-2013) that revealed a worrisome lack of control over several strategic branches of the economy, particularly the electrical and financial sectors and the importation (and distribution) of consumer goods. ${ }^{18}$

In the first quarter of 2003, Venezuela lost about 24.6 percent of its GDP (the annual variation was -7.8 percent) and suffered tremendous capital flight due to heavy political instability: according to the BCV, the most severe recession in the country's history. Even though the barrel price for petroleum was at its lowest point in 22 years when Chavez assumed office in 1998 (Weisbrot et al. 2007), the economy had grown during $2000(+3.7$ percent) and 2001 (+3.4 percent). However, political instability upset this trend over the next two years: in December, 2001, FEDERCAMARAS organized a general business strike against the government that eventually turned into a military coup in April 2002 (led by the entrepreneur and former president of FEDERCAMARAS itself, Pedro Carmona Estanga) that lasted 48 hours. In addition, in December 2002 the opposition led a catastrophic 62-day oil strike that paralyzed oil production. As a result, the rate of unemployment increased from 13.3 percent (2001) to 18.4 percent (2003), and the inflation rate manifested a sharp rise, peaking at 31.1 percent in 2003 (from 12.5 percent in 2001) due to continuous shortages of goods for consumption deliberately provoked by the entrepreneurs adherent to FEDERCAMARAS. Furthermore, the 2007 global economic crisis had serious consequences for Venezuela's economy and evidenced the limits of the growth paradigm implemented by the Chávez administration.

As anticipated, in 2007 the GDP was still growing fast (+8.8 percent) while imports increased by 39.2 percent, essentially at the same intensity as in the previous year ( +40 percent), and this "non-accelerating expansion" of imports was sufficient to determine shortages in the consumer goods market (CEPAL 2012; Weisbrot et al. 2007). Accordingly, the inflation rate rebounded to 18.7 percent (from 13.7 percent in 2006). In addition, after the breakdown of Lehman Brothers, the production of oil slowed (due to the sharp contraction of external demand), thus affecting Venezuela's exports, which suffered a sudden deceleration (then at +4.9 percent, they had grown at +17.7 percent in 2006). Given this new scenario, in 2008 the government chose to increase capital controls as well as to limit the expansion of imports (to "only" +11 percent) in order to avoid external imbalances. However, the administration did not reduce the fiscal stimulus on the economy, probably because exports recovered rapidly (+38 percent). Consequently, GDP grew by 5.3 percent but, in light of the reduced stock of consumer goods available, the inflation rate shot up to 31.4 percent (CEPAL 2012).

Finally, in 2009, the global recession determined further reductions in both external demand and the price of oil. Venezuela's exports drastically decreased (-39 percent) and its GDP contracted (-3.2 percent). It must be noted, however, that the government also dramatically adjusted its expenditures and reduced the fiscal stimulus in order to maintain fiscal balances: the increase in public expenditure did not exceed 1 percent, which was the lowest expansion among Latin American countries, together with Mexico's (Vera 2014). Furthermore, fiscal consolidation

\footnotetext{
${ }^{18}$ The following analysis is focused on the weaknesses of Venezuelan economic policies; however, one should be aware that the difficult circumstances Venezuela currently faces are also the result of interference by the United States and its active de-stabilizing practices across the Latin American region, as was recently recognized by former U.S. Secretary of State Hillary R. Clinton (2014).
} 
implied also an increase in the value added tax (IVA) from 9 percent to 12 percent, counteracting the effect of the reduction of economic activity on the inflation rate, which remained high (28.6 percent) (CEPAL 2012).

The recession continued in 2010 ( -1.5 percent GDP), essentially due to the severe fiscal adjustment (Vera 2014), the low price of oil, and the energy crisis at the Guri Dam that determined lengthy electrical rationing, which in turn greatly affected industrial production, particularly in the iron and steel branches. However, in the fourth quarter of 2010, oil prices rose sharply, limiting the effects of the recession. On January 1, 2010, in order to counteract the strong reduction of exports registered in 2009, the government increased capital controls further and introduced a dual exchange rate: while the exchange rate remained the same (1US $\$=2.6$ bolívares) for imports of food, drugs, and industrial machines and equipment, it substantially increased (to 4.3 bolívares) for any other kind of imported goods. Furthermore, any other class of operation (tourism, remittances, etc.) had to be authorized by a commission known as SITME (Sistema de Transacciones con Títulos en Moneda Extranjera): in this case, the exchange rate was even weaker (1US $\$=5.3$ bólivares). The subsequent restriction to imports $(-14.3$ percent) and their increased price had a negative impact on inflation (at 29.1 percent). However, one should not underestimate the negative role played by the devaluation of the currency, which (as is frequently the case in Latin American economies) rather than increasing exports simply produces an increase in both imported and domestic prices, due to a dragging effect (Vernengo et al. 2009; Fiorito et al. 2013). In particular, Mendoza (2007) has also shown that in Venezuela's case an increase in prices due to devaluation mainly affects the lowest quartile of the income distribution, due to the consumption-based structure of the economy.

On January 1, 2011, the government continued this strategy in order to recover from recession, unifying the overall exchange rate to 4.3 bólivares and maintaining the 5.3 bolívar value for SITME transactions. However, the real recovery came as the result of both fiscal stimulus and the increase in oil prices, rather than devaluation (CEPAL 2011): GDP increased by 4.2 percent; imports registered a moderate expansion of 10.7 percent; and exports expanded thoroughly $(+38$ percent). On the other hand, the inflation rate remained high (27.1 percent); it is also plausible that in this case further devaluation and the restriction to imports were to blame.

The stricter controls on capital and imports, as well as the regulation of the currency market, were suddenly loosened in 2012, probably because of the crucial presidential elections of October. CADIVI authorized imports for the impressive amount of US\$ 61.1 billion (+67.8 percent), which represented the highest-valued quantity of imports in the history of the country. The government also expanded its fiscal policy, financed partly through the high price of oil and partly by means of deficit spending. The result was thorough economic growth $(+5.6$ percent GDP) and a strong deceleration in the inflation rate (to 20.1 percent).

Table 1 and Figure 1 highlight how, in the examined periods, any reduction of imports due to the balance of payments and the deteriorating terms of exchange (or even mere deceleration of their expansion) was associated with an increase in inflation, and vice versa. Therefore, decreasing imports acted as a real pass-through mechanism, determining an increase in costs, which finally impacted on prices. Accordingly, the devaluation of the bolívar (also started in 2010) was matched by high or very high inflation, mainly because this becomes a further source of increasing costs via imports.

However, in 2012 the country faced an unprecedented capital flight which was the combined result of policies implemented since 2003 (and, particularly, from 2010 to the end of 2012). First, after 2006, capital controls and restrictions to the currency market became less effective. On the one hand, the government and the oil company PDVSA issued dollar-valued bonds for an approximate value of US\$ 60 billion, thus implicitly incentivizing the "dollarization" of savings. On the other hand, firms systematically over-invoiced their contracts in order to swindle both the CADIVI and SITME: according to a recent estimation, over-invoicing was 
Table I. Source: Personal elaboration based on CEPAL, BCV, World Bank, and IMF.

\begin{tabular}{lcccccc}
\hline Years & $\begin{array}{c}\text { Nominal } \\
\text { exchange rate }\end{array}$ & $\begin{array}{c}\text { \% var. } \\
\text { imports }\end{array}$ & $\begin{array}{c}\text { Imports/GDP } \\
\text { ratio }\end{array}$ & $\begin{array}{c}\text { \% var. imp/ } \\
\text { GDP ratio }\end{array}$ & $\begin{array}{c}\text { \% var. nominal } \\
\text { exchange rate }\end{array}$ & $\begin{array}{c}\text { \% var. CPI } \\
\text { (Cepal) }\end{array}$ \\
\hline 2003 & 1.60 & $-44 \%$ & $9.98 \%$ & $-6.17 \%$ & $0.0 \%$ & $31.1 \%$ \\
2004 & 1.92 & $82 \%$ & $13.50 \%$ & $3.53 \%$ & $20.0 \%$ & $21.7 \%$ \\
2005 & 2.15 & $44 \%$ & $15.03 \%$ & $1.53 \%$ & $12.0 \%$ & $16.0 \%$ \\
2006 & 2.15 & $40 \%$ & $16.65 \%$ & $1.62 \%$ & $0.0 \%$ & $13.7 \%$ \\
2007 & 2.15 & $39 \%$ & $18.46 \%$ & $1.81 \%$ & $0.0 \%$ & $18.7 \%$ \\
2008 & 2.15 & $11 \%$ & $14.94 \%$ & $-3.53 \%$ & $0.0 \%$ & $31.4 \%$ \\
2009 & 2.15 & $-18 \%$ & $11.67 \%$ & $-3.27 \%$ & $0.0 \%$ & $28.6 \%$ \\
2010 & 2.60 & $-14 \%$ & $8.36 \%$ & $-3.31 \%$ & $20.9 \%$ & $29.1 \%$ \\
2011 & 4.30 & $11 \%$ & $11.52 \%$ & $3.16 \%$ & $65.4 \%$ & $27.1 \%$ \\
2012 & 4.30 & $68 \%$ & $16.04 \%$ & $4.53 \%$ & $0.0 \%$ & $20.1 \%$ \\
2013 & 6.30 & $-29 \%$ & $9.96 \%$ & $-6.08 \%$ & $46.5 \%$ & $56.2 \%$ \\
\hline
\end{tabular}

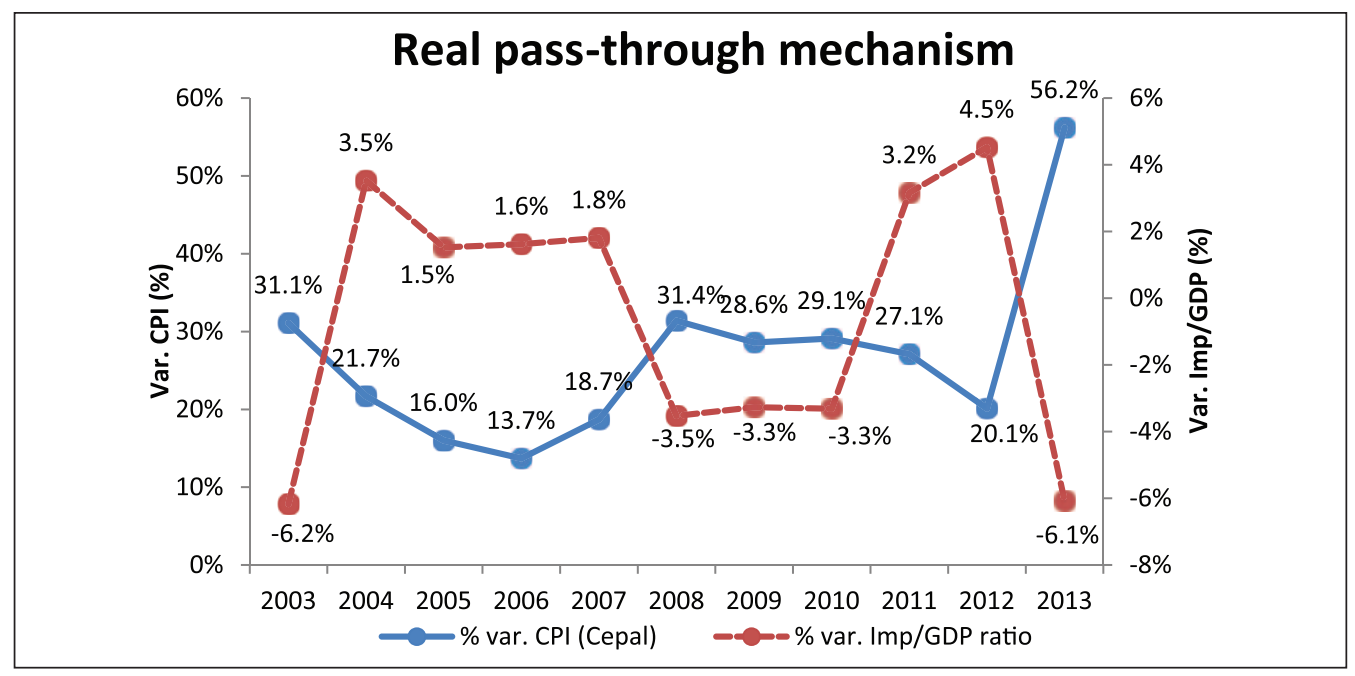

Figure I. Real pass-through mechanism

Source: Personal elaboration based on CEPAL, BCV, World Bank, and IMF.

equivalent to 19.9 percent of total private imports (El Nacional, 21 Jan. 2013). Finally, on the simple condition of maintaining a checking account abroad, it was extremely easy to buy (through a Venezuelan bank) the bonds of any company listed on the New York Stock Exchange, paying in bolívares, and then selling them in New York, obtaining US\$ in exchange. Such capital flight schemes are widespread in Latin America and are conventionally known as contado contra liquidación (cash against documents). Of course, this implicitly reveals the lack of proper regulations in the financial markets and highlights a continuity with the quasi-perfect mobility of capital that has characterized the South American continent since 1980s, including Venezuela.

Second, the loosening of the controls in 2012, together with the enormous volume of authorized transactions throughout this year, facilitated predatory conduct in the currency market. According to the former president of the Central Bank of Venezuela, Chavist Edmee Betancourt, in 2012 approximately US\$ 20 billion of the 60 billion authorized by CADIVI and SITME were appropriated by fake or nonexistent firms (Presidenta del BCV: Parte de los \$59,000 millones 
entregados en 2012 fueron a "empresas de maletín" 2013). On the other hand, denunciations of "suspicious activity" in the financial market brought before the regulating authority (SUDEBAN, or Superintendencia de las Instituciones del Sector Bancario de Venezuela) sharply increased (by 35.70 percent) in 2012 (SUDEBAN 2013).

This parallel supply of dollars (legal, illegal, and "barely legal") has nourished a black market of currency since 2003. The gap between the official exchange rate and the parallel one increased, particularly from 2007, in correspondence to the stricter controls over imports and capital, ultimately resulting in serious problems.

The illegal quotation increased devaluation expectations which triggered a financial passthrough mechanism on prices. On the one hand, firms began to plan their expenditures and to account for their costs as if the currency was weaker than the official quote, thus charging higher final consumer prices. Furthermore, such cost-increasing expectations also determined an increase in shortages, since commodity hoarding became a convenient tactic in light of the expected devaluation (so that the opportunity cost of selling increased relative to hoarding). On the other hand, the black market pressured the exchange rate to depreciate by means of increasing capital flight (induced by speculative expectations) and also encouraged dollar hoarding, which represented an arbitrage opportunity for saving, when compared to the nominal funds rate.

As a result, the trend in the illegal market actually determined the devaluations of the official exchange rate of 2010 and 2011, which fueled the inflation rate and appreciated the real exchange rate. In turn, the latter also impacted on imports, thus retro-feeding the aforedescribed real passthrough mechanism on prices: the result was a self-sustaining inflationary spiral, increasingly difficult to arrest.

Figure 2 shows how the abrupt devaluation of the bolivar in the black market is associated with the acceleration of the inflation that commenced in October 2012 and, eventually, to the devaluation of the (official) nominal exchange rate.

As evidenced by the graph, the sudden loosening of capital controls in 2012 reinforced the devaluatory expectations of the economic agents, who expected that following the October election the conditions of the currency market would sharply worsen. Accordingly, the gap between the official and the parallel exchange rate increased enormously and, eventually, pushed the government to devaluate the bolívar: on January 1, 2013, the national currency's value was reduced by 46.5 percent (from 4.30 to 6.30 bolívares per US\$). Such a strong devaluation was, in turn, accompanied by a dramatic reduction in authorized imports, which fell 28.6 percent in 2013. Therefore, both the financial and real pass-through mechanisms had a mutually destabilizing effect on prices. In 2013, Venezuela's inflation rate was at 56.2 percent and several shortages of consumer goods (including basic goods) affected the economy as imports fell sharply (-29 percent). As a consequence, economic growth was also restricted, to +1.3 percent.

Finally, the situation in 2014 seemed to be further deteriorating, given an estimated GDP contraction of $-4 \%$ (IMF) and an annual inflation rate of 63.4 percent (CEPAL 2014). In order to restrict the destabilizing role of the illegal currency market, the government further segmented the exchange rate: the nominal rate remained unchanged; the reference rate for tourism, gold, and oil (SICAD) was 12 bolívares per US\$. Finally, a market of "contado contra liquidación" was created by the Central Bank in order to "legalize" (and, therefore, limit the damages of) such speculative transactions: the exchange rate (SICAD II) was in this case 49.80 bolívares per US\$. In addition, both CADIVI and SITME were eliminated.

So far, these changes have not managed to stop the overexpansion of the black market, as the estimated breach between the (official) nominal and illegal bolívar exchange rate to U.S. dollars has recently peaked at almost 11,000 percent. Furthermore, grave political instability has been shaking the country for months. 


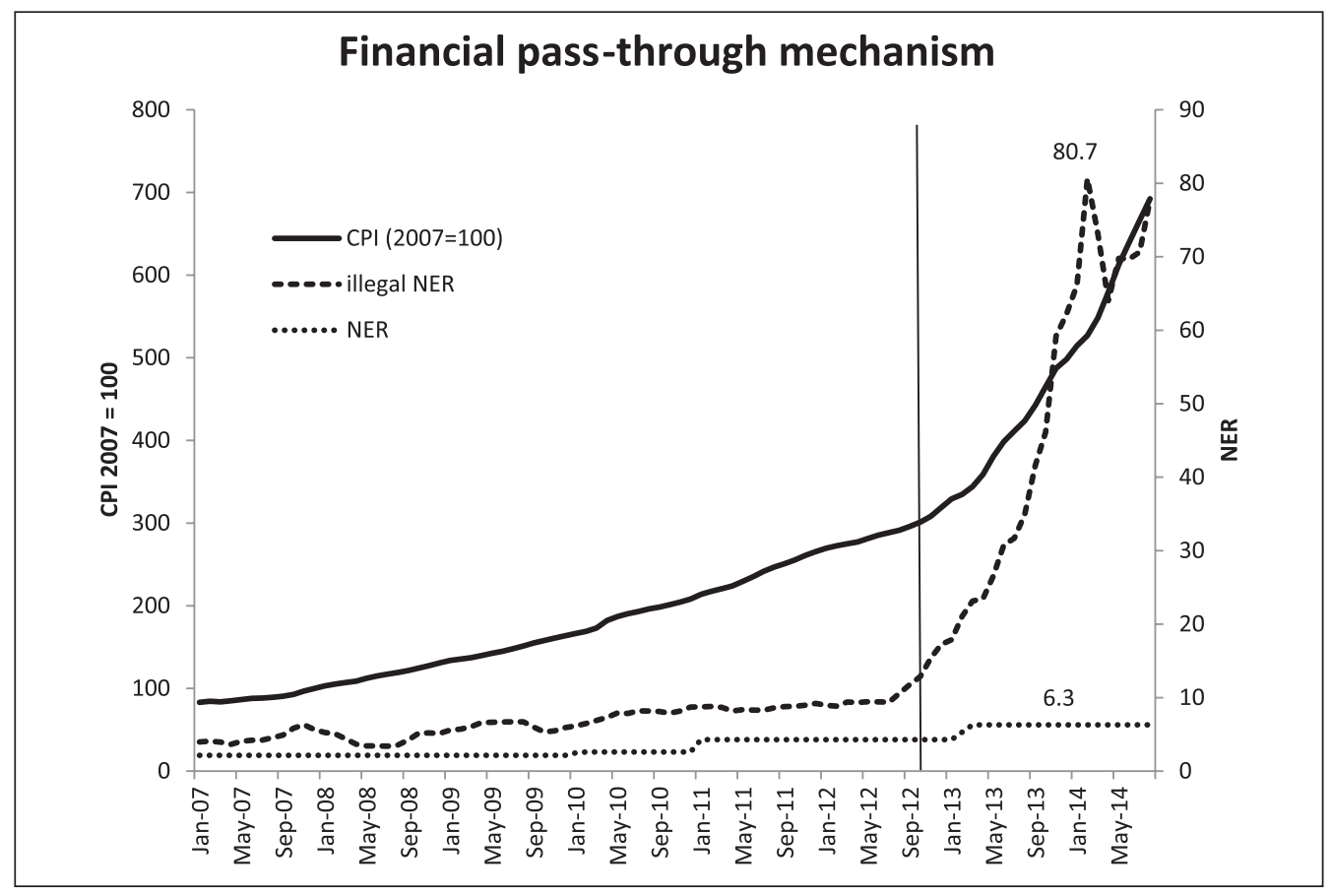

Figure 2. Financial pass-through mechanism

Source: Personal elaboration based on CEPAL, BCV, and dolar-paralel.info.

It is worth pointing out, however, that Venezuela at present is not at risk of economic collapse or even of default on its sovereign debt, since the Central Bank holds US\$21.6 billion in reserves $(\mathrm{BCV})$ - enough to cover at least eight months of imports - and the oil price remains high, although decreasing. Furthermore, opposition economists estimate that there is another US\$15 billion held by other government agencies (Weisbrot 2013), which guarantees more than ample leeway to the economic institutions.

Nevertheless, the main questions that remain are how to explain the problems that Venezuela's economy has been manifesting since 2008 (in order to solve them) and, above all, how long such a scenario can be politically sustainable, also in light of Chavez's death (in 2013). In what follows, we shall deal with these topical issues.

\section{2. "Political aspects of government-pushed development" in Venezuela: A Kaleckian interpretation}

In the previous sections, we found that Chavism adopted a growth model which consisted of a combination of commercial surpluses (guaranteed by oil exports) and subsequent expansion of domestic demand, by means of cheaper imports (which acted as indirect subsidies to domestic consumption), public investments, and social expenditures. Based on the data, I have also emphasized that both the decreasing economic growth and the increasing inflation that have characterized Venezuela since 2008 are permanently associated with restrictions to imports, devaluation of the currency, capital flight, and increasing devaluatory expectations which have been overinflating the illegal currency market.

Accordingly, at this stage of my investigation it becomes necessary to discuss, from a theoretical perspective, the possible interrelation between the growth model adopted by the country and 
the current difficulties of the Venezuelan economy. To this end the works of Michał Kalecki on underdeveloped economies still represent a seminal reference in order to attain a consistent interpretative analysis. ${ }^{19}$

Following Kalecki (1964), we should recognize that in the examined period Chavist Venezuela was neither a socialist nor an intermediate economy. ${ }^{20}$ I might add that it did not even represent the most outstanding example of state interventionism, when compared to the rest of the region. To give a rough idea of the role of the public sector in Venezuela, it is currently equivalent to 30.73 percent of the country's GDP (BCV), whereas throughout Latin America, government expenditures generally average 34.9 percent of GDP, reaching a maximum of 46 percent in Argentina (IMF 2014). Stated succinctly, since 1998 Venezuela has been, to all intents and purposes, a developing capitalist economy. ${ }^{21}$

As regards these economies, Kalecki $(1949,1955,1966)$ repeatedly emphasized a crucial difference with the core of capitalism: given the deficiency of productive capacity, a mere expansion of effective demand by means of "financial tricks" (i.e. public expenditures) would not be sufficient to attain stable economic growth if not matched by an equivalent expansion of productive capacity itself. On the one hand, accelerated economic development induced by state interventionism and abrupt expansion of demand has been relatively easier to achieve in peripheral countries due to their overly depressed effective demand. On the other hand, such development has been difficult to sustain given the economic and social constraints of these countries, which have tended to convert government-pushed economic growth into an inflationary process.

In particular, Kalecki focused on the relationship between inflation and the agricultural primary branch: if agriculture was backwards and unable to guarantee food self-sufficiency to the country, any increase in employment and consumption would immediately generate an increase in the prices of primary goods. Given the consumption-based structure of the underdeveloped economies, any increase in such prices would severely affect real wages, thus provoking quick reaction from the trade unions and, finally, a wage-price spiral (Kalecki 1949, 1966).

Only in the case of favorable terms of exchange may inflation be prevented by means of a thorough expansion of imports, particularly of primary goods. However, as soon as the external scenario worsens, thus inescapably determining a decrease of imports, inflation rises (Kalecki 1955).

On the other hand, the strong demand for primary goods, matched with the insufficiency of the supply-side, would also incentivize predatory conduct, since both the producers (or importers) and the wholesalers (or shopkeepers) might be expected to hoard their stock of commodities instead of selling them, in order to achieve a higher monetary income in the future. Therefore, a black market of primary goods might rapidly rise, generating a further increase in inflation (Kalecki 1949).

According to Kalecki, however, the increase in investment may also generate inflationary pressures if not planned by the government, because the increasing demand for capital goods and equipment would be frustrated by constraint on the balance of payments. In addition, in such a scenario foreign investments would become risky, because inflation would act as an incentive for capital flight by foreign corporations, determining subsequent pressure on the exchange rate and, eventually, an acceleration of the inflationary process itself (Kalecki 1955).

\footnotetext{
${ }^{19}$ An excellent introduction to Kalecki's works on development is in Lopez-Gallardo and Assous (2010), chapter 8.

${ }^{20}$ According to Kalecki's taxonomy, in an intermediate economy capitalist structures have not yet developed; the old feudal classes have been expropriated, so that political power has passed in some cases into the hands of the lower-middle class and peasantry, as in India, Egypt, and Bolivia.

${ }^{21}$ Also given the failure of the 2007 referendum.
} 
Broadly speaking, Kalecki concluded that in peripheral countries, both fiscal stimulus and abrupt expansion of effective demand, although successful in the very short term, usually generate an inflationary process if not matched with a corresponding expansion of productive capacity planned by the government.

Given this general premise, Kalecki's detailed analysis of the Israeli economy (1951) deserves a careful re-reading because of its further similarities with current Venezuela; Israel was at that time characterized by a high percentage of CIF imports ${ }^{22}$ on GDP, an expansionary fiscal policy, and a strong incoming flow of foreign currency (in this case due to massive remittances and donations, rather than oil exports).

In similar cases, not only did the reduction of imports determine an inflationary process and a black market in commodities, but it also led to the emergence of an illegal currency market. First, the accumulation of unspent foreign currency and increasing inflation determined strong capital flight (given the increasing devaluatory expectations) and a demand for foreign currency for hoarding (in order to maintain purchasing power). Second, illegal currency was demanded also to continue consumer goods imports, in order to sell them on the black market, since domestic aggregate demand remained robust due to the fiscal stimulus resulting from government policies. As a result, the Israeli pound was constantly devaluated in the illegal market, eventually driving additional acceleration of inflation. In turn, the accelerated inflation determined an even stronger demand for foreign currency, and a further depreciation of the domestic currency on the black market... and so forth:

...it is clear that any intensification of inflationary pressures will depress the Israeli pound in the black market because a part of unspent incomes will tend to be invested in this way. (Kalecki 1951: 97)

In a parallel work (1949), Kalecki emphasized that the over-expansion of the black market for currency is potentially very hazardous for developing economies: when the aforementioned conditions are fulfilled, the mere attempt by the workers to restore real wages re-ignites a vicious circle of escalating prices, which can increase continuously until degenerating into hyper-inflation.

Accordingly, the solutions suggested by Kalecki implied a radical transformation of the economy: agrarian reform and subsidies to domestic agricultural products in order to reduce the dependence on imports without affecting real wages; a tributary reform in order to finance public expenditures by means of the national currency; planning in order to direct investment only toward the import-reducing branches; rationing and public control of the distribution of primary goods in order to avoid speculation and shortages in the market; a stable exchange rate that would not affect the price of imported goods; the reform of the bank and credit branch in order to intensify controls; and, finally, the creation of fruitful funds in order to channel domestic savings, as well as an adequate level of the interest rate in order to counteract both capital flight and speculation in the illegal currency market (Kalecki 1951, 1955, 1966).

However, Kalecki repeatedly stressed that the practical implementation of similar solutions would encounter "formidable political obstacles" in a non-socialist economy, since they would affect all sorts of vested interests, which are usually much more concentrated and stronger in the peripheral countries. Consequently, any government aiming at reforming its institutions along these lines would face a formidable counteraction by the ruling classes, and even a period of severe social disturbances:

....as a matter of fact, the overcoming of all the obstacles to economic development enumerated above amounts to more than the upheaval created in the eighteenth century by the French Revolution. Thus it is not surprising that these reforms are not peacefully carried out. (Kalecki 1966: 19)

\footnotetext{
${ }^{22} \mathrm{CIF}$ imports are measured using CIF prices (i.e. cost, insurance, and freight prices), that is the prices of the goods before the payment of any import duties or other taxes on imports or trade and transports margins within the country.
} 
From this perspective, Kalecki himself highlighted that in an underdeveloped capitalist economy, the political obstacles that a government must face are much more severe than those described in his well-known 1943 article on the "Political Aspects of Full Employment" in advanced capitalist economies. In other words, the inescapable dilemma that any government has to face is the fact that a radical acceleration of development is impossible if substantial institutional changes are not introduced. On the other hand, mere reform of the existing capitalist institutions is almost unattainable because of the political obstacles typical of peripheral capitalism. I am persuaded that Kalecki's analysis perfectly fits the case of Venezuela presented in this article.

The lack of a diversification in the country's productive structure, together with the absence of significant industrial policies or economic planning programs, certainly represented a significant weakness for Chavist Venezuela. Furthermore, as evidenced by Orhangazi (2014), the agrarian reform implemented by the government was insufficient to solve the structural problems of that branch: as recognized by the Minister of Agriculture, approximately 50 percent of food and agricultural goods are still imported (Yván Gil 2013). Accordingly, any increase in the price of imports automatically affects real wages, thus evolving into "basic inflationary pressures" (Noyola 1956). ${ }^{23}$

In the absence of such reforms, the economic growth in Venezuela largely relied upon oil prices and favorable terms of exchange, which determined the possible maximum level of imports. In the 2003-2007 period, favorable conditions existed such that the expansionary policies succeeded in attaining rapid economic growth. Nevertheless, after the onset of the 2008 global crisis, such a tactic became risky and, inescapably, implied several downturns. In addition, during the crisis years, the international prices for food and other primary commodities increased continuously, thus affecting both the volume of Venezuela's imports and, subsequently, the rate of inflation.

Furthermore, any attempt at reforming the existing institutions triggered political instability: in 2002-2003, even when Chávez had not yet expressed any socialist endorsement, the association of Venezuelan entrepreneurs did not hesitate to paralyze both production and oil extraction, thus sacrificing a vast portion of their profits essentially for reasons of "political stability." The same rule also partly applied in more recent times, as in the 2009-2010 recession, when shortages of primary goods and electrical blackouts suspiciously increased, affecting economic growth; in both these sectors, private entrepreneurs remain in charge. Meanwhile, the national rentiers also played a sympathetic role in this scenario, since capital flight can legitimately be interpreted as an attempt to undermine economic reforms, with the balance of payment representing a constraint on development. This is not surprising, since even the oil branch is not completely nationalized, and several foreign companies (e.g. Chevron, Eni, Total, Gazprom, Repsol) operated or still operate in Venezuela. As we have seen, this has had serious consequences on capital flight, particularly due to over-invoicing. In addition, the financial branch also contributed to capital flight, as proven by the aforementioned increase in denunciations of "suspicious activity" to the regulatory authority SUDEBAN. However, it is difficult to prevent such activities given that private banks still control 64.8 percent of the financial sector (BCV 2012), and also because the Central Bank employed neoliberal policies until 2005. ${ }^{24}$

\footnotetext{
${ }^{23}$ From this perspective, the creation of the Bolivarian Alliance for the Peoples of Our America (ALBA) was certainly a step in the right direction, but it did not allow Venezuela to solve its traditional problems of food self-sufficiency.

${ }^{24}$ Campbell and Cömert (2009) show that, although the Central Bank of Venezuela has remained independent, after 2005 it switched from a predominantly neoliberal to a progressive orientation, in line with the Bolivarian Revolution and changes to the "constitutional framework and to its legislative, judicial, tax, and financial and banking systems, its strategy in international relations, the organization of ministries, and the areas of health, education, and culture" as well as the various social assistance missions created by the executive.
} 
Finally, the decision of the Central Bank to adjust interest rates downwards in order to counteract the decline of GDP over the last two years (Orhangazi 2014) has probably contributed to the over-expansion of the illegal currency market and to capital flight, as dollar hoarding became an (even more) convenient arbitrage opportunity for saving.

In light of this Kaleckian interpretation, it is worth considering the kinds of solutions that might be adopted by the Chavist government in order to achieve both sustainable and accelerated development. And here again we share Kalecki's perspective: it is necessary to drastically reshape both the economic and the political institutions. To my mind, the proposed constitutional draft of 2007 still represents a good starting point. If conceived as a socialist mixed economy, Venezuela would certainly be better able to cope with both the need to differentiate its productive structure (by means of economic planning) and the problem of capital controls (by nationalizing, to a great degree, the financial branch). In addition, attaining such a transformation would require, by definition, overcoming the political obstacles of accelerated development.

Venezuela's entrepreneurs and rentiers seem to be perfectly aware that such a possibility exists, and they have been desperately counteracting such measures for more than a decade. The question remains whether Chavism post-Chávez will be able to come to the same awareness and to act with equal resoluteness.

\section{Concluding Remarks}

The analysis developed in this article highlights the mixed results of the Bolivarian Revolution, starting with Chávez's election in 1998. On the political front, I have shown both its commonalities with (opposition to neoliberalism; anti-political discourse) and its differences from (class and race consciousness; the reference to 21st-century socialism) other progressive governments of the Latin American region, conventionally called "neo-populists." On the economic front, I have emphasized the existence of a Chavist growth model, which consisted of a combination of commercial surpluses (guaranteed by oil exports) and the expansion of domestic demand by means of imports and subsidies to consumption. Subsequently, I have evidenced both the achievements and the critical points of the Chavist growth model (the lack of differentiation in the country's productive structure and its excessive dependency on oil and imports prices). Finally, I have suggested a possible interpretation of the present difficulties facing Chavism, making reference to Kalecki's analysis of the problems of accelerated development in peripheral countries. I have stressed that, in light of the harsh polarization of Venezuelan society, any reprise of conventional regulated capitalism would be unsuccessful, as the lack of control on many strategic branches of the economy (finance, energy, imports) would seriously limit the room for proper economic reforms.

What remains is to suggest some possible lines of intervention in order to positively transform Venezuela's economy. In his seminal work on socialist economies (1937), Oskar Lange dedicated the whole of section 6 to the "Policy of Transition." In short, Lange stressed that any government willing to transform the existing institutions into socialist institutions must face a serious problem: the pre-existing economic system can work only as long as the security of private property and income is maintained. Conversely, the very existence of a government bent on introducing socialism is a constant threat to business security, which leads to resistance and sabotage, since inducements toward making the necessary investments and improvements - as well as to managing plants efficiently - disappear.

Therefore, Lange emphasized that a transition program can scarcely be achieved by gradual steps. Nevertheless, he admitted the existence of a special situation where a socialist government, even when it lacks the power to achieve a comprehensive transition, proves capable of solving a severe economic crisis: in this case, the government can use the popularity won through success in handling economic depression and unemployment in order to pursue "a general attack on the capitalist system" (Lange 1937). 
Following Lange, we may thus conclude that the real challenge that Chavism now faces consists of overcoming the current crisis by means of deep institutional change, along the lines portrayed in the 2007 constitutional referendum. Indeed, the transition to a socialist mixed economy would allow Venezuela to cope, in a more effective way, both with the need to differentiate its productive structure (by means of planning) and with the problem of capital controls (by nationalizing, at least to a considerable degree, the financial branch).

Should the country fail to pursue such reforms, the problems that have affected Venezuela over the last five years will probably worsen, thus threatening the very existence of Chavism, especially if the political scenario in the region further deteriorates and the price of oil continues to decrease. One might therefore say that the Bolivarian dilemma has become a question of whether to revolutionize or perish.

\section{Acknowledgments}

The author wishes to thank Matias Vernengo, Florencia Sember, Modesto Guerrero, Nicolas Zeolla, and the referees for their valuable and helpful comments. The usual disclaimer applies.

\section{Declaration of Conflicting Interests}

The author declared no potential conflicts of interest with respect to the research, authorship, and/or publication of this article.

\section{Funding}

The author received no financial support for the research, authorship, and/or publication of this article.

\section{References}

Arenas, N. 2004. El gobierno de Hugo Chavez: Populismo de otrora y de ahora. Nueva Sociedad 28 (2): $38-50$.

Banco Central de Venezuela, BCV. 2011. Informe económico 2010. Caracas: Versión 25/07/2011.

Banco Central de Venezuela, BCV. 2012. Informe a la Asamblea Nacional sobre los resultados económicos del año 2011. Caracas: Marzo de 2012.

Banco Central de Venezuela, BCV. 2014. 09/09/2014: La variación intermensual del INPC fue de 3,9\% en agosto. Caracas: Nota de Prensa.

Berrettoni, D., and S. Castresana. 2009. Elasticidades de comercio de la Argentina para el período 19932008. Revista del CEI 16: 85-97.

Calcaño, L. G., and N. Arenas. 2002. ¿Modernización autoritaria o actualización del populismo? La transición política en Venezuela. In Venezuela: Rupturas y continuidades del sistema político (1999-2001), ed. L. M. Ramos, 37-68. Salamanca: Ediciones Universidad de Salamanca.

Campbell, A., and A. Cömert. 2009. Progressive Third World central banking and the case of Venezuela. In Economic transitions to neoliberalism in middle income countries, ed. A. Saad-Filho and G. L. Yalman. Routledge.

Cannon, B. 2008. Class/race polarisation in Venezuela and the electoral success of Hugo Chavez: A break with the past or the song remains the same? Third World Quarterly 29 (4): 731-748.

CEPAL. 2011. Estudio económico de América Latina y el Caribe: 2009-2010. Santiago de Chile: United Nations.

CEPAL. 2012. Statistical yearbook for Latin America and the Caribbean. Santiago de Chile: United Nations.

CEPAL. 2014. Desafios para la sostenibilidad del crecimiento en un nuevo contexto externo. Santiago de Chile: United Nations.

Ciccariello-Maher, G. 2007. Dual power in the Venezuelan Revolution. Monthly Review 59 (4).

Cisneros, G. 2009. Prototipo del populismo contemporáneo: El Chavismo y su llegada al poder. Revista de Ciencia Politica 6: on-line archive.

Fiorito, A., N. Guaita, and S. Guaita. 2013. El mito del crecimiento por el tipo de cambio competitivo. Circus. Revista Argentina de Economía 3 (5): 81-104. 
Fuga de capitales en los últimos 10 años sumó \$ 144,9 millardos. 2013. El Nacional, 21 de Enero.

Furtado, C. 1957. El desarrollo reciente de la economia Venezolana. Caracas: Borrador Preliminar, mimeo.

Harnecker, M. 2005. Understanding the Venezuelan Revolution. New York: Monthly Review Press.

Hillary Clinton reviews Henry Kissinger's "World Order.” 2014. The Washington Post, Sept. 4.

Hugo Chávez presenta a Gramsci ante cientos de miles de personas. 2007. Insurgente 09/06. (English edition: Hugo Chavez presents Gramsci to hundreds of thousands of people. A beautiful revolution. http:// axisoflogic.com/artman/publish/Article_24813.shtml )

Kalecki, M. 1943. Political aspects of full employment. Political Quarterly 14 (4): 322-330.

Kalecki, M. 1949. Introductory remarks on inflationary and deflationary processes. In Collected works, ed. J. Osiatynski, vol. 7. Oxford University Press.

Kalecki, M. 1951. Report on the main current economic problems of Israel. In Collected works, ed. J. Osiatynski, vol. 5. Oxford University Press.

Kalecki, M. 1955. The problem of financing economic development. In Collected works, ed. J. Osiatynski, vol. 5. Oxford University Press.

Kalecki, M. 1964. Observations on social and economic aspects of "intermediate regimes." In Collected works, ed. J. Osiatynski, vol. 5. Oxford University Press.

Kalecki, M. 1966. The difference between crucial economic problems of developed and underdeveloped non-socialist economies. In Collected works, ed. J. Osiatynski, vol. 5. Oxford University Press.

IMF. 2014. Fiscal Monitor. Washington, DC, April.

Yván Gil: 'Las fallas no son del modelo socialista, están en la gestión'. 2013. El Mundo, 12/08.

Laclau, E. 2005. On populist reason. London: Verso.

Lander, E. 1996. The impact of neoliberal adjustment in Venezuela, 1989-1993. Latin American Perspectives 23 (3): 50-73.

Lander, E. 2002. El papel del gobierno de EE.UU. en el golpe de estado contra el presidente Chávez. OSALCLACSO working papers, no. 2002/7: 5-11.

Lander, E. 2008. El referéndum sobre la reforma constitucional el proceso político en Venezuela entra en una encrucijada crítica. Revista Venezolana de Economía y Ciencias Sociales 14 (2): 133-166.

Lange, O. 1937. On the economic theory of socialism, part two. Review of the Economic Studies 4 (2): 123-142.

Lange, O., and A. Lerner. 1944. Strengthening the economic foundations of democracy. In American way of business: The role of government in a system of free enterprise, 50-93. Washington, DC: National Council for Social Studies.

Lange, O. 1945. The scope and method of economics. Review of Economic Studies 13 (1): 19-32.

Lopez-Gallardo, J., and M. Assous. 2010. Michal Kalecki. London and New York: Palgrave Macmillan.

Lopez-Gallardo, J. A., and Spanos. 2011. Macroeconomic linkages in Mexico. Metroeconomica 62 (2): 356-385.

McGuire, J. W. 2012. Class structure, distributive conflict, and democracy: Argentina and Brazil in comparative perspective. O'Donnell Fetschrift Papers. Buenos Aires: March 26-27.

Medeiros, C. 2006. Celso furtado e a economia política da abundância de divisas. In Celso furtado e o século XXI, ed. J. Sabóia and F. J. Cardim de Carvalho, 81-109. Sao Paulo: Manole.

Mendoza, O. 2007. Depreciacion, pass-through y desigualdad economica en Venezuela. Central Bank of Venezuela Working Paper No: 81.

Mesa-Lago, C. 2014. What institutional changes come with Cuba's economic reforms? Cuban Economic Change in Comparative Perspective Paper Series. Brookings Institute.

Nakatani, P., and R. Herrera. 2008. Structural changes and planning of the economy in revolutionary Venezuela. Radical Review of Political Economics 40: 292-299.

Noyola, J. 1956. El desarrollo economico y la inflacion en Mexico y otros paises Latinoamericanos. Investigacion Economica 16: 603-48.

Presidenta del BCV: Parte de los $\$ 59.000$ millones entregados en 2012 fueron a 'empresas de maletín.' 24/05/2013. www.aporrea.org

O‘Donnell, G. 1978. State and alliances in Argentina, 1956-1976. Journal of Development Studies 15 (1): 3-33.

Orhangazi, Ö. 2014. Contours of alternative policy making in Venezuela. Review of Radical Political Economics 46 (2): 221-240. 
Ramos Jiménez, A. 2002. Partidocracia y democracia plebiscitaria. El ascenso de un nuevo régimen en Venezuela. Iconos. Revista de Ciencias Sociales 12: 111-121.

Reyes, O. 2006. Sobre el socialismo del siglo XXI en Venezuela. Stockolm Review of Latin American Studies 1: 84-104.

Rodriguez, F. R. 2003. Las consecuencias económicas de la Revolución Bolivariana. Revista Nueva Economía 19: 85-142.

Roncaglia, A. 2005. The wealth of ideas. A history of economic thought. Cambridge University Press.

SUDEBAN. 2013. Informe de retroalimentacion segundo semestre 2012. Caracas: Venezuela.

Vera, L. 2014. Venezuela 1999-2013: Macro-policy, oil governance and economic performance. Conference paper "central banking in Latin America." Buenos Aires: CEDES, 28-29 August.

Vernengo, M., and C. E. Schonerwald da Silva. 2009. Foreign exchange and the dynamics of public debt in Latin America. In The political economy of the public budget in the Americas, ed. D. SanchezAncochea and I. Morgan, 104-123. Institute for the Study of the Americas.

Weisbrot, M. 2013. Sorry, Venezuela haters: This economy is not the Greece of Latin America. The Guardian, 7 November.

Weisbrot, M. 2008a. How not to attack an economist (and an economy): Getting the numbers right. Center for Economic and Policy Research. Issue brief, April.

Weisbrot, M. 2008b. Poverty reduction in Venezuela: A reality-based view. ReVista, Harvard Review of Latin America (Fall): 1-7.

Weisbrot, M., and L. Sandoval. 2007. The Venezuelan economy in the Chávez years. Center for Economic and Policy Research, July.

\section{Author Biography}

Roberto Lampa is a Full Researcher at the CONICET (National Scientific and Technical Research Council) and a Professor at the Universidad Nacional de San Martin, Buenos Aires, Argentina. He holds a $\mathrm{PhD}$ in history of economic thought from the University of Macerata, Italy. He has been a visiting scholar at the Université Paris 1 Pantheon-Sorbonne and at the New School for Social Research. 